\title{
SEED-FEEDING BEETLES (BRUCHINAE, CURCULIONIDAE, BRENTIDAE) FROM LEGUMES (DALEA ORNATA, ASTRAGALUS FILIPES) AND OTHER FORBS NEEDED FOR RESTORING RANGELANDS OF THE INTERMOUNTAIN WEST
}

\author{
James H. Cane ${ }^{1}$, Clarence Johnson², Jesus Romero Napoles ${ }^{3}$, Douglas A. Johnson ${ }^{4}$, \\ and Robert Hammon ${ }^{5}$
}

\begin{abstract}
Aвstract.-Seed-feeding beetles of the genera Acanthoscelides, Apion, and occasionally Tychius were commonly found occurring in seeds from wild populations of Astragalus filipes and Dalea ornata across rangelands of the United States Intermountain West, resulting in many new state, county, and host records. These 2 legumes, as well as other perennial herbaceous species, are being commercially farmed to produce seed supplies to rehabilitate sagebrush-steppe and adjoining juniper woodlands following wildfires. Most of the seeds examined in this study hosted one or more seedfeeding beetles; beetles that pupate and overwinter in the seeds pose the risk of being transported to storage warehouses and distributed to new seedings, unless the beetles are first detected and then controlled.
\end{abstract}

Resumen.-Encontramos escarabajos que se alimentan de semillas de los géneros Acanthoscelides, Apion y, ocasionalmente, Tychius en semillas de poblaciones silvestres de Astragalus filipes y Dalea ornata en los pastizales de la zona montañosa del oeste de Estados Unidos, lo cual incrementó los registros en el estado, el condado y de nuevos huéspedes. Estas dos legumbres y otras especies herbáceas perennes se cultivan a nivel comercial con el fin de producir la reserva de semillas para rehabilitar las estepas de artemisa y los bosques de enebros después de incendios forestales. La mayor parte de las semillas que examinamos en este estudio alojaron a uno o más escarabajos; los que se transforman en pupas y pasan el invierno en las semillas corren el riesgo de ser trasladados a depósitos de almacenamiento y ser distribuidos a nuevas semillas a menos que sean detectados y controlados con anterioridad.

Several favorable factors must align for flowering plants to sexually reproduce. Some are intrinsic to the plant (e.g., age, health), and others are external, either abiotic (e.g., rainfall) or biotic. Among biotic factors, insect pollinators are often needed for seed production. Ovule fertilization is no guarantee of successful reproduction, however, because predispersal frugivores and seed predators often consume or damage maturing seeds both in agricultural fields and wildland environments (Crawley 1992).

Some beetles and wasps are common seed predators whose larvae feed within one or several individual seeds. Seed-feeding beetles are represented by several taxa: mostly true weevils (Curculionidae) (e.g., Anderson and Howden 1994), seed beetles (Chrysomelidae: Bruchinae) (particularly Acanthoscelides) (Johnson 1981), and pear-shaped weevils (Brentidae: Apioninae) (Kissinger 1968). Crops, especially legumes, can be plagued by these seed-feeding beetles (e.g., bean weevil) (Johnson 1981), with some Callosobruchus being especially destructive because they can produce multiple generations in dry stored beans and pulse crops.

Efforts to revegetate or restore degraded native plant communities on public rangelands have gained momentum in recent years. Increasing wildfire frequencies fueled by invasive annual grasses have devastated native plant communities across millions of hectares of rangelands in the western United States, impoverishing biodiversity, diminishing forage for livestock and wildlife, degrading nutrient and water cycles, and accelerating soil erosion and stream sedimentation (Sheley et al. 2008). At these larger spatial scales, planting firedamaged rangelands with seed is often the sole practical option to improve degraded conditions, speed recovery, and prevent further

\footnotetext{
${ }^{1}$ USDA-ARS Pollinating Insect Research Unit, Utah State University, Logan, UT 84322-5310. E-mail: jim.cane@ars.usda.gov

${ }^{2}$ Deceased. Formerly of the Department of Biology, Northern Arizona University, Flagstaff, AZ.

${ }^{3}$ Programa de Entomología y Acarología CEIFIT, Colegio de Postgraduados Montecillo, Estado de Mexico, Mexico.

${ }^{4}$ USDA-ARS Forage and Range Research Lab, Utah State University, Logan, UT 84322-6300.

${ }^{5}$ Tri River Cooperative Extension, Grand Junction, CO 81502.
} 
erosion. Native forb and grass seed is either harvested from wildlands, or increasingly, produced commercially on farms. In their seed mixes for revegetation, land managers often prefer a mix of diverse species, including native legumes. Seed-feeding beetles can be expected to be problematic, given their common association with seeds of sundry forbs, but scant attention has been given to beetles in native seed crops. Concerns relative to seed viability for commercial seed production include (1) seed damage, (2) transport of infested seed to seed growers in other states where emerging adults could colonize their seed fields, and (3) inadvertent transfer into seed storage warehouses where some beetle species might be able to multiply in stored live seed.

The objective of this study was to survey for insect seed predators attacking common wildflowers of the sagebrush-steppe in the Intermountain Region of the western United States. We focused specifically on several species of Fabaceae being targeted for commercial seed production through the auspices of the Great Basin Native Plant Selection and Increase Project (GBNPSIP) funded by the USDI Bureau of Land Management (BLM) and administered through the USDA Forest Service, Rocky Mountain Research Station. In this study, we documented the taxonomic identities of these seed predators, their host associations and geographic occurrences, and several pertinent aspects of their life histories.

\section{METHODS}

We used locality data from herbarium specimens to help find populations of basalt milkvetch (Astragalus filipes Torr. ex A. Gray) from which to collect seeds. We manually collected and bulked mature seed pods from at least 100 plants for each of 67 individual wildland sites in July and August 2003 (Bhattarai et al. 2008). These sites collectively represent much of this milkvetch's geographic distribution (California, Idaho, Nevada, Oregon, Utah, and Washington), spanning 8 Level III Ecoregions (Omernik 1987). Similarly, 22 seed collections of western prairie clover (Dalea ornata [Douglas ex Hook.] Eaton \& J. Wright) were obtained from Washington, Idaho, and Oregon (4 Level III Ecoregions) during summer 2005 (Bhattarai et al. 2010). The average collection had 18,600 and 22,800 seeds, respectively. Site data reported in those studies included elevation, latitude, and longitude.

Beetles were manually extracted from the separate seed collections after the seeds were air-dried in a greenhouse and mechanically separated from their pods. Additional adult beetles were noted and collected from flowers during a 6-state survey of pollinators at these forbs. We also opportunistically collected seedfeeding beetles from 1-3 populations of several other prevalent forb genera desired for rehabilitating Great Basin plant communities (Hedysarum, Lomatium, and Sphaeralcea). Voucher specimens of the beetles are deposited in the insect collections of Utah State University and the Smithsonian Institution National Museum of Natural History.

Evidence for the commercial implications of seed crop infestation by seed predators came from a 5 -acre field of $D$. ornata being grown for seed in Washington. The grower sent representative samples of the bulked harvested seed, as well as seed that had been cleaned using a gravity table. Seed contents (endosperm vs. weevil) were visualized by digital X-radiography (Faxitron MX-20, $25 \mathrm{KV}$, 30 -second exposure), and image interpretations were checked with dissected seed.

\section{Results And Discussion}

Seed-feeding beetles were prevalent among collections of legume seed from the Great Basin. All are minute in size. Among the 22 bulk seed samples of $D$. ornata seed examined for seed predators, only 3 lacked adult beetles altogether. Most D. ornata sites across the sampled 3-state region yielded mixed seed infestations of both Apion amaurum Kissinger and Acanthoscelides oregonensis Johnson (Fig. 1, Table 1; Cane et al. 2012). At the 29 sites where sampled populations of As. filipes hosted seed-feeding beetles, only one seed-feeding beetle species, Ac. pullus (Fall), was nearly ubiquitous. It feeds on more diverse hosts than many of its more restricted congenerics (Johnson 1981). The several other seed-feeding beetle species from As. filipes were found in fewer than $25 \%$ of the seed collections (Fig. 2, Table 1).

The New World genus Acanthoscelides is the largest in the beetle subfamily Bruchinae, with 340 described species (Kingsolver 1989). 


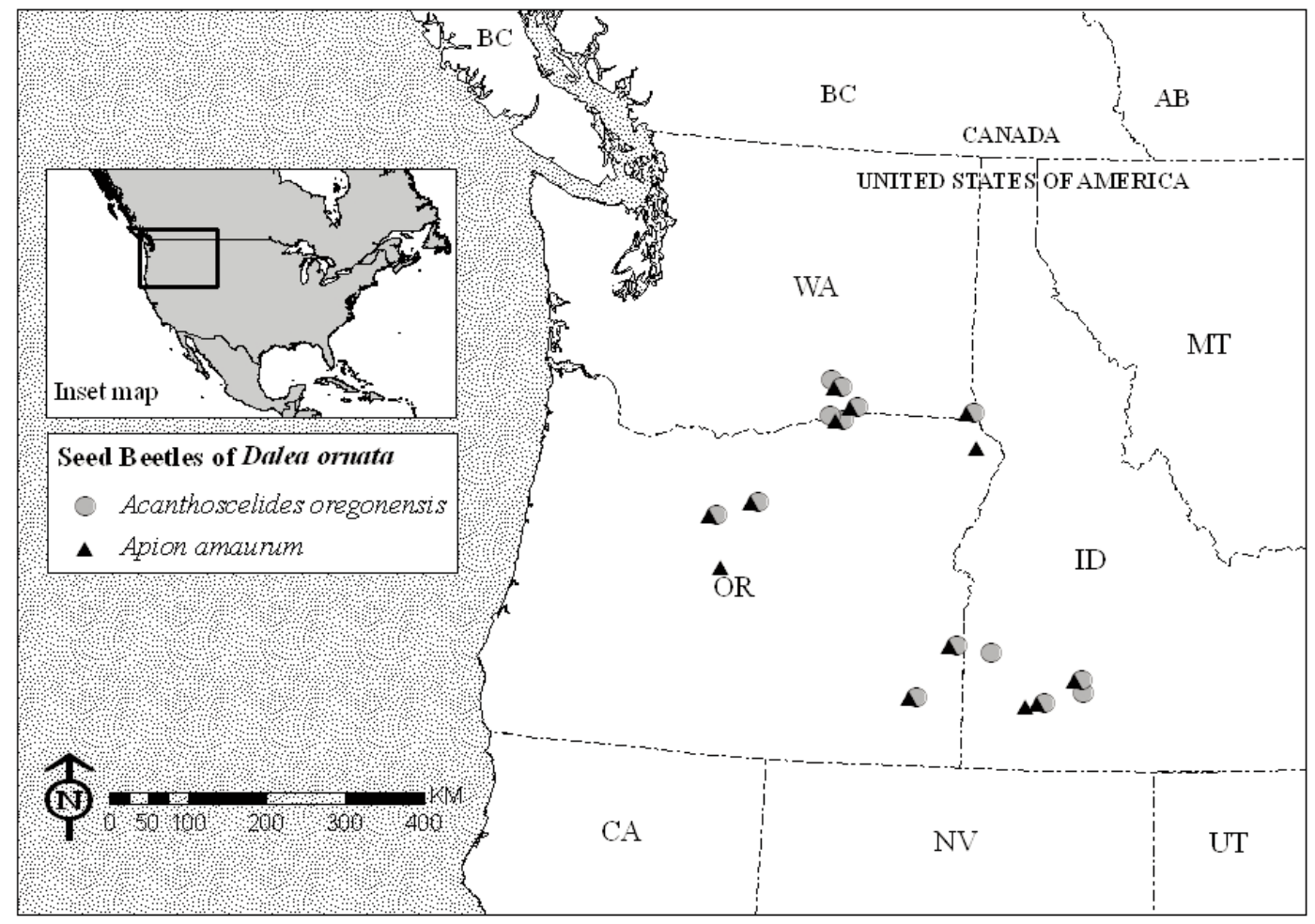

Fig. 1. Populations of Dalea ornata where seed-feeding beetles were present either in collected seed or at flowers.

TABLE 1. State and county records for seed-feeding beetles infesting legume seeds from this study.

\begin{tabular}{|c|c|c|}
\hline Host & Beetle species & States and counties \\
\hline \multirow[t]{2}{*}{ Dalea ornata } & Acanthoscelides oregonensis & $\begin{array}{l}\text { IDAHO: Canyon*, Elmore*, Owyhee*. OREGON: } \\
\text { Jefferson*, Malheur, Umatilla*, Wheeler*. } \\
\text { WASHINGTON: Asotin*, Benton*, Franklin*, } \\
\text { Walla Walla*. } 76 \text { specimens. }\end{array}$ \\
\hline & Apion amaurum & $\begin{array}{l}\text { IDAHO: Elmore*, Owyhee*. OREGON: Crook*, } \\
\text { Jefferson*, Malheur, Umatilla*, Wallowa*, } \\
\text { Wheeler*. WASHINGTON: Asotin*, Franklin*, } \\
\text { Walla Walla*. } 80 \text { specimens. }\end{array}$ \\
\hline \multirow[t]{2}{*}{ Astragalus filipes } & & $\begin{array}{l}\text { OREGON: Baker*, Crook*, Harney*, Klamath, } \\
\text { Morrow*, Wheeler*. } 30 \text { specimens. }\end{array}$ \\
\hline & Acanthoscelides pullus & $\begin{array}{l}\text { CANADA: British Columbia*. IDAHO: Butte*, } \\
\text { Clark*, Owyhee*. NEVADA: Elko*. OREGON: } \\
\text { Baker*, Crook*, Harney*, Jackson*, Jefferson*, } \\
\text { Klamath*, Wasco*. UTAH: Box Elder*. } \\
\text { WASHINGTON: Grant*. } 95 \text { specimens. }\end{array}$ \\
\hline
\end{tabular}

*New county or state record

Its species are found from Canada south to Argentina and Chile; a minority (16\%) are found in the United States (Kingsolver 2004). Larval bruchines are seed predators, feeding in seeds and pupating in the seed or pod/capsule of their host. Species differ in the number of generations per year; many are univoltine.
They attack at least 35 families of plants, but the Fabaceae account for $85 \%$ of the reported hosts (Johnson 1981). These large numbers could be misleading, though, as the genus is not likely to be monophyletic with respect to other genera of New World Bruchinae (Johnson 1983; D. Morse personal communication). 


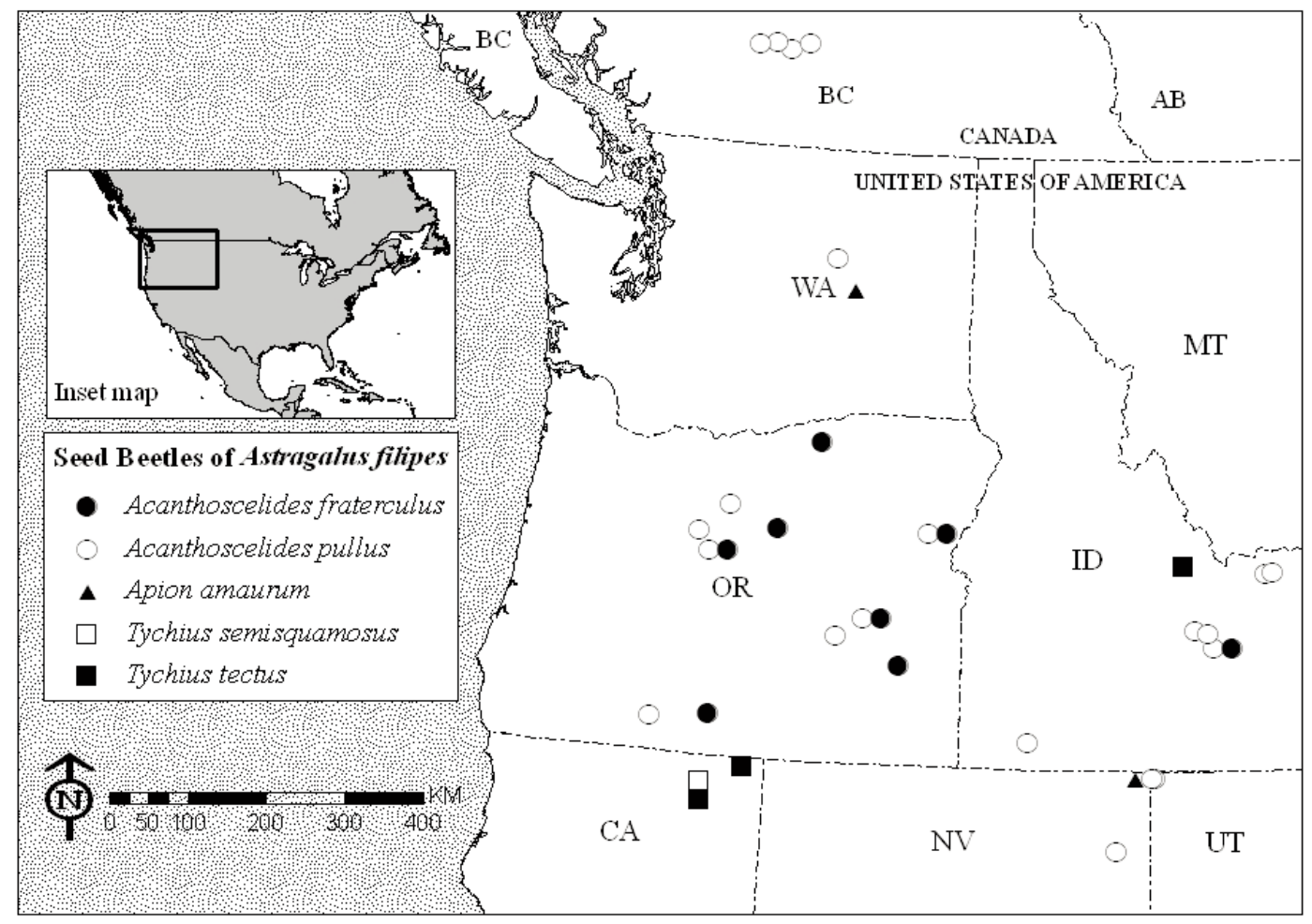

Fig. 2. Populations of Astragalus filipes where seed-feeding beetles were present either in collected seed or at flowers.

However, all species of Acanthoscelides found in this survey are from a group of species that is likely to be monophyletic (the Puellus species group, Johnson 1983); these primarily feed in seeds of North American herbaceous legumes.

Diverse species of Acanthoscelides are represented in seeds of the legume genera that we sampled. Eleven species of Dalea host one or more of 7 Acanthoscelides species (Kingsolver 2004). One or more of 8 Acanthoscelides species feed in seeds of $>35$ Astragalus species, more than any other host genus (Kingsolver 2004). Among the species of Acanthoscelides with the most hosts are Ac. fraterculus and Ac. pullus (Johnson 1981), which we isolated from seed of As. filipes. Adults are only $1.5-3.0 \mathrm{~mm}$ long. We also reared 26 Ac. fraterculus from seed of northern sweetvetch, Hedysarum boreale Nutt. (Fabaceae) collected from Colorado, Utah, and Washington. Several cryptic species may compose Ac. fraterculus, each with its particular legume host (D. Morse, personal communication). Ac. fraterculus is recorded from seed production fields in Colorado, where it caused significant crop damage (Johnson 1990); we have observed it in most $H$. boreale seed production fields we have visited. Species with multiple seed hosts, such as Ac. pullus, could be transported within seed of various native legumes, or could switch to infest populations of a given host legume established with a restoration seeding or on a farm.

Of the 1500 named species of pear-shaped weevils (Apioninae) worldwide, most are tropical or subtropical, but 300 species are found in North and Central America (Kissinger 1968). Species whose larvae feed in seeds are scattered through many genera, including the large genus Apion. Although most of the subgenus Apion (Pseudapion) consists of Old World species, North and Central America have 15 species, all of them associated with legumes, usually their seeds (Kissinger 1968, 1988). Kissinger (1968) warned that identification of these miniscule (1.5-2.0 mm length) beetles is difficult, with no single reference collection in existence. The species of Apion that we collected is in Kissinger's Varicorne 
group; it is indistinguishable from Ap. amaurum of that group, which is the representative of Varicorne reported from the states where we collected it (Kissinger 1968).

A number of Apion species have been reared from (or are suspected to attack) seeds of legume genera represented in the Great Basin flora. One Apion species has been reported from seeds of lupines (Ap. proclive Leconte), another from $H$. boreale (Ap. alaskanum Fall), but until now, no host records existed for the largest legume genus, Astragalus (Kissinger 1968, 1988). Nine Apion species are known to develop in seeds of Dalea, but of these, most are found either in the southern warm deserts, the Great Plains, or in the southeastern United States (Kissinger 1988). Kissinger (1968) reported rearing Ap. amaurum reared from Petalostemon (= Dalea) seed in Washington but did not specify the Dalea species. Only D. ornata occurs where he reported that collection, and that legume is the host from which we repeatedly reared Ap. amaurum.

Adults of 2 species of the weevil genus Tychius were collected at flowers and developing seed pods of As. filipes. Six T. tectus LeConte came from near Canby in Modoc County, California; 15 T. semisquamosus LeConte came from that same site as well as nearby Fandango Pass (near Goose Lake), and from Big Gulch in Custer County, Idaho. These all represent first state records (Clark 1971). Both species were known to occur in the western United States and adjacent portions of Canada and Mexico (O'Brien and Wibmer 1982). Adults are small $(2.5-4.0 \mathrm{~mm}$ long). North America has 12 native and 4 introduced species of Tychius (O'Brien and Wibmer 1982, Anderson and Howden 1994). Species of Tychius infest seeds of diverse legume genera, including Astragalus, Baptisia, Hedysarum, Lotus, Lupinus, Melilotus, Oxytropis, Teline, and Trifolium (Clark 1971, Anderson and Howden 1994). Besides T. semisquamosus, other congeners are known to infest seed of Astragalus (Clark 1971, 1977, Green and Palmblad 1975), but none had been reported from $A$. filipes before now.

Clark and Burke (1977) stated that Tychius adults are encountered on plants on which larvae develop. Larvae feed on seeds within the pods, then exit the pods and enter the soil to pupate. They apparently overwinter as adults in pupal cells in the soil to emerge in the spring when their hosts are in the proper stage of growth for weevil feeding and oviposition. They appear to undergo a single generation per year. Seed damage can be extensive; for Astragalus australis, a western North American species, Tychius destroyed as much as $80 \%$ of the species' seed production, making this predispersal seed predator the most important factor limiting reproductive success of A. australis (Kaye 1999).

Seed-feeding beetles associated with other restoration forbs were also encountered while we collected bees at flowers or processed harvested seed. From umbels bearing young developing seeds of Lomatium dissectum (Nutt.) Mathias \& Constance (Apiaceae), we collected 13 adult Smicronyx weevils near Logan, Cache County, Utah. This difficult weevil genus comprises 70 species in North America; most feed on seeds or form galls on herbaceous species (Anderson 1962). Among those that infest seeds, mature larvae reportedly exit the seeds to pupate underground where they overwinter (Anderson 1962). These weevils are generally not reported from the Apiaceae. However, an experimental seed predation study of another biscuitroot, L. grayi (Ellison and Thompson 1987), detailed the considerable damage caused by larvae of Smicronyx cinereus feeding in developing Lomatium seed in the field.

Seed-feeding weevils were found on several species of globemallow (Sphaeralcea, Malvaceae). The weevil Anthonomus sphaeralciae Fall (Coleoptera: Curculionidae) was found infesting $25 \%$ of the developing flowers found in a seed production field of Sphaeralcea coccinea (Nutt) Rydb. in Delta County, Colorado (Hammon and Franklin 2012). These weevils lay eggs in flower buds; their larvae feed within the developing ovaries. This weevil was also found in seed production fields in Montezuma County, Colorado, and Malheur County, Oregon (Hammon and Franklin 2012). Adults of the seed-feeding weevil Macrorhoptus hispidus Dietz (Curculionidae) were found on flowers of S. grossularifolia in Utah. Both Macrorhoptus and Anthonomus are closely allied, having species that attack seeds of herbaceous Malvaceae (Burke 1973). Only 6 species of Macrorhoptus are found in the central or western United States, all associated with herbaceous species. In contrast with 
most other seed-feeding weevils, larvae of this genus pupate in their natal seed capsules (rather than dropping to the soil), where they apparently overwinter to emerge as adults the following year (Burke 1973).

These seed predators can substantially diminish seed yields, especially for plants under cultivation, necessitating regular scouting and a safe method of control by growers. Youtie and Miller (1986) reported that 3 neighboring wild populations of As. filipes sustained $62 \%$ and $93 \%$ pod damage from larvae of seed predators (moths and weevils) in sequential years. For 2 other Great Basin species of Astragalus, reported seed damage by Ac. fraterculus was $60 \%$ and $74 \%$ in the wild (Green and Palmblad 1975). At one farm, we found many early-flowering racemes of $D$. ornata with one or more adult Acanthoscelides beetles across a 5-acre commercial seed field in central Washington. Protected inside the pod (and seed), larvae cannot be controlled by conventional insecticide surface sprays, but could be susceptible to some systemic insecticides. Young adult seed-feeding beetles also feed, but on the foliage or pollen of their host plants, probably to gain nutrients needed to mature their eggs (Tuttle 1954, Anderson 1962, Clark and Burke 1977, and references therein). Conventional insecticide sprays applied to the seed crop could be used to kill feeding preoviposition adult beetles, but there would be collateral damage to bees that visit all of the forbs used in the GBNPSIP Program. These forbs require, or benefit from, bee pollination (Cane et al. 2012, Swoboda and Cane 2012; e.g., Watrous and Cane 2011). It follows that conventional insecticides used to kill adult beetles would kill bees as well (Johansen and Mayer 1990), thereby extinguishing necessary pollination services for multiple years.

In the wild, a few natural enemies that might be used as biological control agents have been reported for these beetle genera. The vespid wasp Euparagia scutellaris Cresson sometimes provisions its subterranean nests with paralyzed larvae of Smicronyx weevils (Trostle and Torchio 1986). Some sphecid and eumenid wasps provision their nests with paralyzed adult weevils (Bohart et al. 1982) and, in a few cases, bruchines (Scullen and Wold 1969). Parasitic wasps (Braconidae, Eulophidae, Eupelmidae, Eurytomidae, Pteromalidae, Torymidae) have been reared from seed infested by larval seed-feeding beetles, including multiple species of Acanthoscelides, Apion, and Tychius (Tuttle 1954, Center and Johnson 1976, Clark and Burke 1977, Hetz and Johnson 1988, and references therein). Although these potential biological control agents could be sufficiently numerous on some seed farms to suppress seed-feeding beetle populations, especially where farms are adjacent to wildland areas, it is currently impractical to mass-rear these species for inundative releases.

Harvest, storage, and transport of seed infested with live seed-feeding beetles are justified concerns. Such a "Trojan horse" scenario could result in establishment of seed-feeding beetle populations transported outside of their geographical range, inoculation of new forb fields on farms, and introduction with postfire seedings. Species of Acanthoscelides and Apion are known to pupate in the pod cavities or within individual seeds, from which they later emerge as adults (Tuttle 1954, Johnson 1981, and references therein); these were the life stages that we obtained from wildland seed collections. In contrast, mature larvae of true weevils exit their host seeds to pupate in the soil (Anderson 1962, Clark and Burke 1977), but with exceptions such as Macrorhoptus (Burke 1973). Shallow cultivation could control those that pupate in the soil beneath their host plants, except that nearly all of the forbs under study or in production for use in the Great Basin are perennials. Beetles that overwinter as adults in seeds pose the greater risk for transport. Before bagging and storage, suspect seed could be sampled for infestation (much as was done for this project). Methods already in use for pests of stored products, specifically methods safe for live seed, should be explored for effective treatments for infested seeds of these rangeland forbs (e.g., mechanical seed cleaning, fumigation, abrupt freezing, controlled atmospheres) (Banks and Fields 1995). The raw harvested seed of $D$. ornata from the Washington seed farm was $4 \%-5 \%$ infested by seed-feeding beetles. After separation and cleaning using a gravity table, discarded seed was only $2 \%$ live seed, the remainder being infested seed (15\% live larvae, $63 \%$ dead larvae, $7 \%$ adults, and $13 \%$ empty seed coats). Alternatively, for our small seed collections, we successfully killed beetles within seeds with the conventional insecticide 
fumigant dichlorovos (details in Bhattarai et al. 2010) without harming the live seed.

\section{ACKNOWLEDGMENTS}

We thank Melissa Weber for extracting beetles from many of the seed collections. Many seed collections were made by Kevin Connors, who was constantly attentive to insect associates. Dr. Wayne Clark (Auburn University) kindly provided authoritative identification for the species of Tychius and Smicronyx. This research was funded by the Great Basin Native Plant Selection and Increase Project through the USDI-BLM Great Basin Restoration Initiative and the USDA Forest Service, Rocky Mountain Research Station. Additional taxonomic expertise with bruchines was given by Dr. Geoffrey Morse. We are also grateful to him, Dr. Nancy Shaw, and 2 anonymous reviewers for detailed, constructive revisions. We dedicate this publication to the late Dr. Clarence Dan Johnson. Dan was an ever-helpful, enthused master of all things bruchine.

\section{Literature Cited}

Anderson, D.M. 1962. The weevil genus Smicronyx in America north of Mexico (Coleoptera: Curculionidae). Proceedings of the United States National Museum 113:185-372.

ANDERson, R.S., AND A.T. Howden. 1994. Tychius meliloti Stephens new to Canada with a brief review of the species of Tychius Germar introduced into North America (Coleoptera: Curculionidae). Canadian Entomologist 126:1363-1368.

Banks, H.J., AND P.G. FIELDS. 1995. Physical methods for insect control in stored grain. Pages 353-409 in D.S. Jayas, N.D.G. White, W.E. Muir, and R.N. Sinha, editors, Stored grain ecosystems. Marcel Dekker, Inc., New York, NY.

Bhattarai, K., B.S. Bushman, D.A. Johnson, and J.G. Carman. 2010. Phenotypic and genetic characterization of western prairie clover collections from the western United States. Rangeland Ecology and Management 63:696-706.

Bhattarai, K., D.A. Johnson, T.A. Jones, K.J. Connors, AND D.R. Gardner. 2008. Physiological and morphological characterization of basalt milkvetch (Astragalus filipes): basis for plant improvement. Rangeland Ecology and Management 61:444-455.

Bohart, G.E., F.D. Parker, and V.J. Tepedino. 1982. Notes on the biology of Odynerus dilectus [Hym.: Eumenidae], a predator of the alfalfa weevil, Hypera postica [Col.: Curculionidae]. BioControl 27:23-31.

Burke, H.R. 1973. Taxonomic relationships and biology of Macrorhoptus (Curculionidae). Coleopterists Bulletin 27:175-181.

Cane, J.H., M. Weber, and S. Miller. 2012. Breeding biologies, pollinators, and seed beetles of two prairie-clovers, Dalea ornata and Dalea searlsiae (Fabaceae: Amorpheae), from the Intermountain West, USA. Western North American Naturalist 72:16-20.

Center, T.D., AND C.D. Johnson. 1976. Host plants and parasites of some Arizona seed-feeding insects. Annals of the Entomological Society of America 69: 195-201.

Clark, W.E. 1971. A taxonomic revision of the weevil genus Tychius Germar (Coleoptera: Curculionidae) in America north of Mexico. Brigham Young University. Science Bulletin, Biological Series 13:1-28.

1977. North American Tychius: new synonymy and observations on phylogeny and zoogeography (Coleoptera: Curculionidae). Entomologica Scandanavica 8:287-300.

Clark, W.E., and H.R. Burke. 1977. The curculionid genus Tychius Germar: natural history and coevolution with leguminous host plants. Southwest Entomologist 2:106-120.

Crawley, M.J. 1992. Seed predators and plant population dynamics. Pages 157-191 in M. Fenner, editor, Seeds: the ecology of regeneration in plant communities. CAB International, Wallingford, United Kingdom.

Ellison, R.L., AND J.N. ThOMPson. 1987. Variation in seed and seedling size: the effects of seed herbivores on Lomatium grayi (Umbelliferae). Oikos 49: 269-280.

Green, T.W., and I.G. Palmblad. 1975. Effects of insect seed predators on Astragalus cibarius and Astragalus utahensis (Leguminosae). Ecology 56:1435-1440.

Hammon, R., and M. Franklin. 2012. Seed-feeding insects impacting globemallow seed production. Native Plants Journal 13:95-97.

HetZ, M., AND C.D. Johnson. 1988. Hymenopterous parasites of some bruchid beetles of North and Central America. Journal of Stored Products Research 24:131-143.

Johansen, C.A., AND D.F. MaYer. 1990. Pollinator protection: a bee and pesticide handbook. Wicwas Press, Cheshire, CT.

Johnson, C.D. 1981. Relations of Acanthoscelides with their plant hosts. Pages 73-81 in V. Labeyrie, editor, The ecology of bruchids attacking legumes (pulses). Dr. W. Junk Publishers, The Hague, Netherlands. 1983. Ecosystematics of Acanthoscelides (Coleoptera: Bruchidae) of southern Mexico and Central America. Miscellaneous Publications of the Entomological Society of America 56. 370 pp.

1990. Confirmation of Hedysarum boreale Nuttall (Leguminosae) as a host plant for Acanthoscelides fracterculus (Horn) (Coleoptera: Bruchidae). PanPacific Entomologist 66:175-176.

KaYe, T.N. 1999. From flowering to dispersal: reproductive ecology of an endemic plant, Astragalus australis var. olympicus (Fabaceae). American Journal of Botany 86:1248-1256.

KingsolveR, J.M. 1989. New World Bruchidae past, present, future. Pages 121-129 in K. Fujii, A.M.R. Gatehouse, C.D. Johnson, R. Mitchell, and T. Yoshida, editors, Bruchids and legumes: economics, ecology and coevolution. Proceedings of the Second International Symposium on Bruchids and Legumes, Kluwer Academic Publishers, London.

2004. Handbook of the Bruchidae of the United States and Canada (Insecta: Coleoptera). United States Department of Agriculture Technical Bulletin no. 1912, Volume 1. 
Kissinger, D.G. 1968. Curculionidae subfamily Apioninae of North and Central America. Taxonomic Publications, S. Lancaster, MA.

1988. New host and distribution records for Apionidae from North and Central America (Coleoptera). Coleopterists Bulletin 42:302-304.

O’Brien, C.W., AND G.J. Wibmer. 1982. Annotated checklist of the weevils (Curculionidae sensu lato) of North America, Central America, and the West Indies (Coleoptera: Curculionidae). Memoirs of the American Entomological Institute, no. 34. 382 pp.

OMERnik, J.M. 1987. Ecoregions of the conterminous United States. Annals of the Association of American Geographers 77:118-125.

Scullen, H.A., AND J.L. Wold. 1969. Biology of wasps of the tribe Cercerini, with a list of the Coleoptera used as prey. Annals of the Entomological Society of America 62:209-214.

Sheley, R., J. Mangold, K. Goodwin, and J. Marks. 2008. Revegetation guidelines for the Great Basin: considering invasive weeds. ARS-168. USDA Agricultural Research Service, Washington, DC. $52 \mathrm{pp}$.
Swoboda, K.A., And J.H. Cane. 2012. Breeding biology and incremental benefits of outcrossing for the restoration wildflower, Hedysarum boreale Nutt. (Fabaceae). Plant Species Biology 27:138-146.

Trostle, G.E., And P.F. Torchio. 1986. Notes on the nesting biology and immature development of $\mathrm{Eu}$ paragia scutellaris Cresson (Hymenoptera: Masaridae). Journal of the Kansas Entomological Society 59:641-647.

TutTle, D.M. 1954. Notes on the bionomics of six species of Apion. Annals of the Entomological Society of America 47:301-307.

Watrous, K.W., and J.H. Cane. 2011. Breeding biology of the threadstalk milkvetch, Astragalus filipes (Fabaceae), with a review of the genus. American Midland Naturalist 165:225-240.

Youtie, B.A., AND R.F. MiLler. 1986. Insect predation on Astragalus filipes and A. purshii seeds. Northwest Science 60:42-46.

Received 25 April 2013 Accepted 12 September 2013 